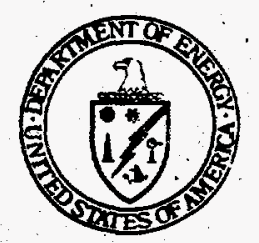

\title{
Federal Facility Compliance Act Implications for RCRA Corrective Action
}

BACKGROUND: The Federal Facility Compliance Act (FFCAct) was signed into lew on October 6, 1892. This Act, which amends the Solid Waste Disposal Act (as amended by the Resource Conservation and Rocowery Act (RCR A), makes major changes to ealsting sections of RCRA as they apply to Federal faclltios and adds provisions that specifically address waste fesues germane to the Department of Enerey (DOE). The moet slonticent and farreaching provision of the FFCAct is the statute's waiver of the Federal government's soverelen immunity. This waiver will now give the Environmental Protection Agency (EPA) and the various stutw authortaed bolinplinent the RCRA program the authority to require ".esech department, agency, and instrumentalthy of the Uniled States...." to comply with all relevant substantive and procedural requirements of RCRA. Thls provision essentially places all Federal facilities on the same compliance footing as private industry and may resilt in punitive fines if violations occur. In addition to the sovereign immunity waiver, other important bseuses addressed by the FFCAct include the following provisions: 1) States are allowed to colloct fines, penaltios, and oreraight fees from federal entities; 2) EPA or authorized Statos are required to conduet ysarby RCRA hapections at Federal facillties and to seek reimbursement from those facillies for all inspection costs; 3) DOE must evaluate the inventory of radioactive mixed wastes it currenthy controls and investigate present and future treatmemt capacity and technologies for the management of DOE mixed wastes; 4) the management of RCRA wastes on public vessels are governed; 5) EPA is required, in consultation with the Department of Defense (DOD), to promulgate regulations addressing waste military munitions and their safe transport and storage; and 6) Federally Owned Treatment Works (FOTWs) and the types of westes they may manage are governed. Provisions 1,3 , and 6, above, are of particular relevance to the RCRA Corrective Action program and are highitghted in this Information Brief.

STATUTE: The Federal Facilities Compliance Act (Public Law 102-386), the Resource Conservation and Recovery Act (RCRA)(Public Law 94-580), and the Hazardous and Solid Waste Amendments of 1984 (HSWA) (42 USC $\$ 6901$, et seq.).

REGULATIONS: There are currently no regulations promulgated under the FFCAct; however, this information Brief discusses the implications of the Act regarding "Corrective Action for Solid Waste Management Units at Hazardous Waste Management Facilities; Proposed Rule" 55 FR 30798, July 27, 1990.

REFERENCES: 1. "Joint Explanatory Statement on the FFCAct of the Committes of Gonference," House Conference Report No. 102-886, September 22, 1992.

2. "Corrective Action Management Units and Temporary Units; Corrective Action Provisions; Final Rule," 58 FR 3658, February 16, 1993.

3. "Corrective Action Management Units and Temporary Units," U.S. Department of Energy, Office of Environmental Guidance, RCRAJCERCLA Division, RCRA Information Brief, EH-231-04310394 (March 1994).

4. "Publication of Schedule for Submitting Plans for Treating Mixed Waste Generated or Stored at Each Site as Required by the Federal Facility Compliance Act of 1992," 58 FR 17875, April 6, 1993.

How does the FFCAct waiver of sovereign immunity affect the corrective action process?

The waiver of the Federal government's sovereign immunity will have a dramatic effect upon the relationship between Federal departments, agencies and instrumentalities, and regulatory agencies such as EPA and States authorized to implement RCRA in lieu of EPA. Previously, Federal facilities, such as those owned by DOE, were immune from most EPA or authorized State enforcement authorities. fines, and penalties. Now, Federal entities are subject to all the provisions of RCRA, including Federal and State enforcement mechanisms. This new authority will allow regulators to enforce milestones or deadlines identified in Federal Facility Compliance Agreements, consent orders, or other binding administrative clean-up orders. Such requirements may be built into corrective action permits and orders as a means of requiring Federal entities to implement effective corrective action measures. For example, if a DOE facility fails to comply with all permit requirements that were made as the result of a RCRA Facility Investigation
(RFI), penalties ma, be assessed against DOE for failure to comply with stipulated permit conditions. In addition to Federal penalties that might be assessed for noncompliance, States that are authorized to implement the corrective action program in lieu of EPA may also seek enforcement under their own authorities.

\section{Will regulatory audits of DOE facilities be mandatory?}

The FFCAct Sections 104(1) and (2) requires EPA to conduct annual RCRA inspections of all Federal facilities. As part of the first inspection, the regulator is required to "...conduct a comprehensive ground water monitoring evaluation...'? 'unless such an evaluation was conducted in the preceding 12 months. Authorized States are permitted to conduct inspections at Federal facilities to ensure compliance with State hazardous waste regulation.

Under the FFCAct Section 104(4), a Federal agency is required to reimburse EPA for the costs of facility inspections. States are 1"lowed to-recover the costs of inspections under the authority 
granted in Section 102(3). The implication for corrective action is that these inspections, which include periodic progress inspections, will require the facility to reimburse all eligible expenses incurred by the regulator.

\section{How are remediation wastes that are mixed wastes affected by the FFCAct?}

The waiver of sovereign immunity applies to all Federal entities as of October 6, 1992; however, one notable exception to this waiver was stipulated in the FFCAct. Federal and State regulators may not pursue civil, criminal, or administrative penalties and fines for violations of the Land Disposal Restriction (LDR) storage prohibition for "'mixed wastes" [40 CFR 268:50] for a period of three years after enactment of the FFCAct. Mixed wastes are defined by the FFCAct as those wastes that contain both RCRA hazardous waste and source, special nuclear, or by-product material subject to the Atomic Energy Act (AEA) of 1954 [42 USC 2011 , et seq.]. In addition, the FFCAct Section 102(c)(3)(B) stipulates that DOE will be sheitered from mixed waste storage violations as long as DOE: submits plans under FFCAct Section 105(b) for developing treatment capacities and technologies for each facility that generates mixed wastes; and is in compliance with the approved plans pursuant to an order issued by a regulatory agency.

Since mixed wastes are likely to be generated by DOE facilities undertaking corrective action remediation activities, such wastes would also be subject to a delayed effective date for mixed waste as long as they are not subject to existing agreements, permits, or administrative or judicial orders. If wastes are subject to an agreement, or order, they must be managed in a manner that is in compliance with those documents. In response to FFCAct Section 105(c), DOE published a schedule for submitting plans for developing mixed waste treatment capacities and technology as required under the FFCAct Section 105(b)(Reference 4). As long as DOE continues to meet this schedule and has an approved plan and order in place by October 1995, DOE's mixed waste (including mixed waste generated during RCRA corrective action) will not be subject to fines and penalties relative to violations of the LDR storage prohibition. Moreover, mixed waste, at some sites, may be exempt from the site treatment plans requirement if they are covered by an agreement or similar mechanisn with the State, or the plan may be waived in lieu of a different type of agreement and order.

Mixed wastes generated by remediation activities undertaken during the corrective action process may be managed using corrective action management units (CAMUs). Under the CAMU regulations, RCRA wastes generated during corrective actions (i.e., remediation wastes) are not required to meet technologybased treatment levels established under the LDR prior to being placed within a CAMU. Mixed wastes would be eligible for management in such a unit as long as the additional requirements of the AEA are also met. The AEA requirements are primarily performance-based standards that must be met in order to be considered protective of the environment and human health. Mixed wastes that would be considered for incorporation into a CAMU (such as a landfill) would be limited in that no wastes identified as transuranic or high-level mixed waste would be considered. Various Federal, State, and local requirements conceming the sitespecific design of the CAMU would have to be addressed. In addition. future liability from the management of remediation wastes in CAMUs would have to be considered, since legal action has already been taken by various environmental and industry groups against EPA's CAMU rule. Further, since the CAMU rule is considered to be less stringent than existing RCRA regulations, it is not an available option in States that are already authorized for corrective action until those States adopt the CAMU rule. Nevertheless, while the descision to utilize CAMUs for the management of remediation wastes, which are also mixed waste, is complex, it is a potentially viable means for waste management and warrants further consideration at DOE facilities.

\section{Can corrective action wastes be treated in federally owned treatment works?}

The statutory language of the FFCAct amends the existing statutory definition of solid waste to further define the exemption for "...solid or dissolved material in domestic sewage...." Under the amendment, solid or dissolved materials in domestic sewage that are discharged to federally owned treatment works (FOTWs) are exempt from the statutory definition of solid waste, provided that they meet at least one of the following criteria:

Materials must be subject to a pretreatment standard under Section 307 of the Clean Water Act (provided the source is in compliance with established pretreatment standards).

- Materials not currently subject to a pretreatment standard use subject to an EPA-promulgated schedule for establishing such standards before October 6, 1999 (provided that (1) the standard is in effect prior to or on the date set forth in the schedule and (2) the source is in compliance after the effective date of the standard).

$\square$ Materials not covered under either ci the above criteria must be treated by appropriate technologies or to established concentration standards specified by the RCRA LDR regulations.

0 The generator is considered a RCRA household or a conditionally exempt small quantity generator (CESQG) by generating either less than 100 kilograms of hazardous waste or less than 1 kilogram of acutely hazardous waste per month.

In addition to those materials or CESQG waste limitations identified above; the FFCAct prohibits the introduction of a RCRA hazardous waste into a FOTW. This prohibition does not include the above cited exceptions (i.e., they are not solid wastes and therefore cannot be considered hazardous wastes) nor does it include other materials expressly exempted from RCRA Subtitle C.

Based on the considerations stated above, use of FOTWs as a means of further treating or disposing of certain kinds of corrective action wastes (primarily wastewaters) is viable as long as the wastes in question are treated to a concentration meeting Clean Water Act pretreatment or RCRA LDR standards.

Questions of policy or questions requiring policy declsions will not be addressed in EH-231 Information Briefs uniless that policy has already been established through appropriate documentation. Please refer any questions. concerning the subject matter covered in this Information Brief to Jerry Coalgate, RCRACERCLA Division, EH-231, (202) $586-6075$

\section{C}

\section{.}

